\title{
Effects of High Salinity on Survival, Growth, and Reproductive performance of Red Tilapia (Oreochromis urolepis hornorum $O \times$ Oreochromis mossambicus ơ)
}

\section{Benjamin C. Young 1,2*, Riyadh Hussain Alfaggeh1, Ibrahim AlMoutiri ${ }^{1}$, Winton Cheng ${ }^{3}$}

\author{
1 Jeddah Fisheries Research Center, Ministry of Environment, Water \& Agriculture, Jeddah \\ 21423, Saudi Arabia \\ 2 Taiwan International Cooperation and Development Fund, Taipei 11047, Taiwan \\ ${ }^{3}$ Department of Aquaculture, National Pingtung University of Science and Technology, \\ Neipu 91201, Taiwan
}

Key words: Red Tilapia; Growth performance; Fry production; High salinity

\begin{abstract}
This study estimated the survival, growth, and fry production of red tilapia (Oreochromis urolepis hornorum $Q \times$ Oreochromis mossambicus $O^{\prime}$ ) broodstock in outdoors farming conditions at various salinity levels (1\%o, $25 \%$, 33\%o, $39 \%$, and $42 \%$ ) at $25.3^{\circ} \mathrm{C}-39.0^{\circ} \mathrm{C}$. The experiments were conducted in triplicates in 2020 using 300 broodstock per group. The survival rate, growth performance, and fry production were monitored. Our results showed that red tilapia fry production and grow-out farming were feasible under high salinity conditions; however, the various levels of salinity condition exhibited significant differences in terms of survival rate, growth performance, fry production. The results suggest that red tilapia broodstock was maintained under salinity as high as 33\%o without impairing fry production; above 33\%o was feasible for the grow-out stage, implying that the fry production in euryhaline tilapia farming would be practical in regions where freshwater acclimation is limited.
\end{abstract}




\section{Introduction}

Tilapia (Oreochromis spp.) farming is important for economic development, market demand, and food security in Saudi Arabia (Siddiqui and Al-Harbi, 1995; Elhendy and Alzoom, 2001; Young et al., 2021b). Saudi Arabia presently manufactures about 75,400 tons of aquaculture; Pacific white shrimp (Litopenaeus vannamei) farming accounted for $\sim 80 \%$ in 2019. The primary farmed tilapia species, Nile tilapia (Oreochromis niloticus), Sabaki tilapia (Oreochromis spilurus), Mozambique tilapia (Oreochromis mossambicus), hybrid tilapia (Oreochromis niloticus $\times$ Oreochromis aureus), and red tilapia (Oreochromis urolepis hornorum $Q \times$ Oreochromis mossambicus $\sigma^{7}$ ), have contributed 9,000 tons to Saudi Arabia's total fish production in 2019 (Food and Agriculture Organization of the United Nations, 2022).

Because of the limitations dictated by government policies and environmental restrictions, euryhaline tilapia is becoming more suitable for aquaculture than freshwater tilapia (Young et al., 2021ab). Red tilapia has been gaining possible popularity and is one of the high-valued tilapia farming species in Saudi Arabia (Siddiqui and Al-Harbi 1995; ElZaeem et al., 2012).

Despite significant improvements in red tilapia aquaculture in Saudi Arabia, there is little information on outdoor commercial farming operations under high salinity. Because of West Saudi Arabia, the saltiness of seawater is about $42 \%$ \% $-45 \%$ o (Saunders et al., 2016; Young et al., 2021a). For ideal conditions of red tilapia farming, seawater salinity is about 1\%o-18\%o (Watanabe et al., 1989; El-Zaeem et al., 2012). Furthermore, the high cost of freshwater acclimation is an essential parameter affecting Saudi tilapia aquaculture production costs. Regulations strictly prohibit the installation of pumping wells (Elhendy and Alzoom 2001; Al-Hafedh et al., 2008; Young and Alfaggeh 2021). However, a lack of information exists on the outdoor culture of the red tilapia in high-salinity conditions. Most related research has been at lower salinity (1\%o-37\%o), fingerling size $(>1 \mathrm{~g})$, or indoor hatchery condition (Watanabe et al., 1990; Romana-Eguia et al., 1999; El-Zaeem et al., 2012; Sallam et al., 2017). Therefore, this study was designed to increase our understanding of the outdoor culture of red tilapia under high-salinity conditions.

\section{Materials and Methods}

\section{Experimental design}

The red tilapia broodstock for this study was grown from January 1st to December 31st, 2020, and obtained from the Jeddah Fisheries Research Center, Jeddah, Saudi Arabia. The experiments were conducted in triplicate at a $10-\mathrm{m}^{3}$ capacity outdoor raceway tank with 300 broodstock per system. The red tilapia broodstock average weight was $244.6 \pm 20.62-$ $\mathrm{g}$, and the female-to-male sex ratio was $2: 1$. The broodstock maintained in tanks at salinities of salinity $1 \%$, $25 \%$, $33 \%$, $39 \%$, and $42 \%$ were picked from broodstock from freshwater acclimation. Broodstock was acclimated to $1 \%-42 \%$ at a rate of $3 \%$ o per day. Broodstock was maintained salinity acclimated 30 days. After acclimating, broodstock were transferred directly into raceway tanks at various levels of salinity $(1 \%$, $25 \%$, $33 \%$, $39 \%$, and $42 \%$ ).

The frequency, feed quantity, and feeding competition were controlled manually. Commercial feed (floating, $6-\mathrm{mm}, 36 \%$ crude protein, $4 \%$ crude fat, Arasco, Saudi Arabia) was used twice daily ad libitum.

The daily water exchange was about $10 \%$ of the tank volume by controlling the water valve and monitoring the salinity. The temperature ranged from $25.3^{\circ} \mathrm{C}-39.0^{\circ} \mathrm{C}, \mathrm{pH} 5.17-$ 7.45, and dissolved oxygen (DO) $4.50-6.70-\mathrm{mg} / \mathrm{L}$ at all groups. The dead fish, uneaten feed, and fecal matter were removed twice daily. The broodstock in all groups were randomly sampled and measured once every week between 06:00 and 08:00 $\mathrm{h}$. Additionally, the fry were sampled once every 30 days to determine the survival rate, growth performance, and fry production. The formulation of growth performance was adopted from a previous record (Young et al., 2021a; Young and AlMoutiri, 2022). 
The survival rate was calculated as follows: the number of survivors at the end of the experiment $\times 100 /$ initial number stocked.

The specific growth rate (SGR) was determined using the following equation: specific growth rate $(\%$ body weight per day) $=[(\ln (W 2-W 1)) \times 100] / \Delta t$, where $W 1$ represents the initial wet fish weight at stocking, W2 represents the final wet fish weight, and $t$ represents the grow-out period. The feed conversion ratio (FCR) was determined by feed weight/fish weight gain.

\section{Statistical analyses}

The data were analyzed using IBM Predictive Analytics Software (PASW) 18.0 (IBM, Armonk, New York) using ANOVA and Duncan's multiple range test for post hoc comparison of the means. $p<0.05$ was considered significant.

\section{Results}

The maximum salinity endured by the red tilapia broodstock was $42 \%$ (Table 1 ). The survival rate varied significantly between various salinity groups throughout the experiment $(p<0.05)$, especially in the group exposed to salinity levels of $42 \%$, which indicated a lower survival rate (45\%) and growth performance $\left(0.49 \%\right.$ day $\left.^{-1}\right)$. The highest salinity endured production were the 39\%o group, and 1\%o-33\%o group with the higher survival rate and fry production among the five salinity groups (Table 1).

Table 1 Red tilapia survival rate, Feed conversion ratio, Specific growth rate (\% day ${ }^{-1}$ ), and fry production per female at different salinities

\begin{tabular}{|c|c|c|c|c|}
\hline Salinity & Survival rate (\%) & $\begin{array}{l}\text { Feed conversion } \\
\text { ratio }\end{array}$ & $\begin{array}{l}\text { Specific growth rate } \\
\left(\% \text { day }^{-1}\right)\end{array}$ & $\begin{array}{l}\text { Mean fry production } \\
\text { per female } \\
\text { (30 days) }\end{array}$ \\
\hline $1 \%$ & $95.7 \pm 0.2^{a}$ & $1.37 \pm 0.05^{a}$ & $0.83 \pm 0.06^{a}$ & $202 \pm 8^{a}$ \\
\hline $25 \%$ & $93.6 \pm 3.2^{a}$ & $1.45 \pm 0.23^{b}$ & $0.75 \pm 0.17^{b}$ & $173 \pm 49^{a}$ \\
\hline $33 \%$ & $93.2 \pm 2.5^{a}$ & $1.63 \pm 0.15 c$ & $0.64 \pm 0.08 c$ & $179 \pm 57^{a}$ \\
\hline $39 \%$ & $77.0 \pm 1.3^{b}$ & $1.71 \pm 0.37^{d}$ & $0.60 \pm 0.09^{d}$ & $71 \pm 11^{b}$ \\
\hline $42 \%$ & $45.0 \pm 5.0^{c}$ & $1.86 \pm 0.86^{e}$ & $0.49 \pm 0.17^{e}$ & $0 \pm 0^{d}$ \\
\hline
\end{tabular}

In each column, different letters indicate a significant difference $(p<0.05)$.

\section{Discussion}

Our results showed that the salinity of $42 \%$ was the maximum endured for red tilapia farming. Additionally, Stickney (1986), Watanabe et al. (1989), Romana-Eguia et al. (1999), Cnaani and Hulata (2011), and El-Zaeem et al. (2012) showed that the maximum endured for red tilapia was about 16\%o-39\%o from previous research groups and commercial hatcheries. Under increased salinity conditions, the survival rate of red tilapia farming was $45 \%-77 \%$, which was consistent with the results reported by Sallam et al. (2017) showed survival rate of red tilapia farming was $81 \%-100 \%$ under $36 \%$. Additionally, Watanabe et al. (1989) reported that the maximum salinity endured by red tilapia fry production was $36 \%$ salinity; our results maximum salinity survived by red tilapia fry production was under 39\%o condition. Additionally, Watanabe et al. (1989) and Sallam et al. (2017) reported that the red tilapia fry production was 90-210 per spawning period under $36 \%$ salinity conditions; our results indicated that it was 100 fry per spawning period under $39 \%$ o salinity conditions.

The growth performance of this study was consistent with the results reported by Romana-Eguia et al. (1999) and Sallam et al. (2017) that showed that SGR was 0.49\%$0.85 \%$ day $^{-1}$. Furthermore, it was noted that the body color of red tilapia under high salinity is lighter than freshwater red tilapia. Considerable variations in water quality parameters (temperature, $\mathrm{DO}$, and $\mathrm{pH}$ ) were not observed between all groups in this study when the climate was relatively stable. 
The higher FCR and lower survival rate in the high salinity groups were likely induced by increased stress levels in the farming environment, which places fish under high salinity $\left(42 \%\right.$ ) and temperature stress $\left(38^{\circ} \mathrm{C}\right)$ conditions (Saunders et al., 2016; Young et al., 2021a). El-Zaeem et al. (2012), and Sallam et al. (2017) reported that the red tilapia obtained the higher growth performance was cultured in brackish water (15\%o) or seawater (25\%o to $36 \%$ ) which was consistent with the results reported in this study. Moreover, diseases, especially parasitic and bacterial infections, frequently occur in fish farming in the winter. Additionally, it was noted that diseases, including bacterial and parasitic infections are frequent in outdoor farming systems of red tilapia during the winter. We also noted that feed, labor and freshwater were the main cost-related factors in red tilapia farming, consistent with the tilapia culture results reported in Saudi Arabia by Elhendy and Alzoom (2001), and Young et al. (2021ab). Additionally, the freshwater cost $(0 \%-29.67 \%)$ was an essential parameter that influenced the production costs of tilapia farming in Saudi Arabia. Although most aquaculture companies in Saudi Arabia are either industrial or large-scale businesses, most tilapia farming are small-scale businesses. In aquaculture development, this is vital because the scale of farming operations makes a significant difference. For example, Young et al. (2021b) reported that industrial-scale tilapia producers spent less on feed in Saudi Arabia because they could manufacture feed at their facilities. In contrast, Zhang et al. (2016) found that small-scale Chinese fish producers were economically inefficient. Furthermore, Young et al. (2021b) and Young and AlMoutiri (2022) reported that limiting environmental factors and higher-cost production facilities were more common in fish farming in Saudi Arabia.

The results of this study on the efficacy of commercial-scale red tilapia farming systems in Saudi Arabia could be used to inform related research and to further develop aquaculture techniques for euryhaline tilapia farming.

\section{Acknowledgements}

The authors thank the Jeddah Fisheries Research Center, Saudi Arabia, for providing all the materials.

\section{References}

Al-Hafedh, Y. S., Alam, A., \& Beltagi, M. S., 2008. Food production and water conservation in a recirculating aquaponic system in Saudi Arabia at different ratios of fish feed to plants. Journal of the World Aquaculture Society 39, 510-520.

https://doi.org/10.1111/j.1749-7345.2008.00181.x

Cnaani, A., \& Hulata, G., 2011. Improving salinity tolerance in tilapias: past experience and future prospects. Israeli Journal of Aquaculture-Bamidgeh 63, 21. https://doi.org/ 10.46989/001C.20590

Elhendy, A. M., \& Alzoom, A. A., 2001. Economics of fish farming in Saudi Arabia: analysis of costs of tilapia production. Aquaculture Economics and Management 5, 229238. https://doi.org/10.1080/13657300109380289

El-Zaeem, S. Y., Ahmed, M. M. M., Salama, M. E. S., \& Darwesh, D. M. F. 2012. Production of salinity tolerant tilapia through interspecific hybridization between Nile tilapia (Oreochromis niloticus) and red tilapia (Oreochromis sp.). African Journal of Agricultural Research 7, 2955-2961. https://doi.org/10.5897/AJAR12.061

Food and Agriculture Organization of the United Nations, 2022. Global aquaculture production. Food and Agriculture Organization of the United Nations, Rome. Available: http://www.fao.org/fishery/statistics/global-aquaculture-production/query/en. (January 2022)

Romana-Eguia, M. R. R., \& Eguia, R. V., 1999. Growth of five Asian red tilapia strains in saline environments. Aquaculture 173, 161-170.

https://doi.org/10.1016/S0044-8486(98)00484-0

Sallam, G. R., Fayed, W. A., El-Absawy, M. A., Aly, H. A., \& El-Greisy, Z. A., 2017. Red tilapia broodstocks and larval production under different water salinities without 
acclimation. Journal of Aquaculture Research Development 8, 476. https://doi.org/10.4172/21559546.1000476

Saunders, J. F., Cardia, M. S., Hazzaa, B., Rasem, M. A., Othaibi, M. I., \& Rafiq, M. B., 2016. Atlas of potential areas for cage aquaculture: Red Sea - Kingdom of Saudi Arabia. Food and Agriculture Organization of the United Nations, UTF/SAU/048/SAU, Rome, Italy.

Siddiqui, A. Q., \& Al-Harbi, A. H. 1995. Evaluation of three species of tilapia, red tilapia and a hybrid tilapia as culture species in Saudi Arabia. Aquaculture 138, 145-157. https://doi.org/10.1016/0044-8486(95)01088-2

Stickney, R. R., 1986. Tilapia tolerance of saline waters: a review. The Progressive FishCulturist 48, 161-167.

https://doi.org/10.1577/1548-8640(1986)48<161:TTOSW>2.0.CO;2

Watanabe, W. O., Burnett, K. M., Olla, B. L., \& Wicklund, R. I., 1989. The effects of salinity on reproductive performance of Florida red tilapia. Journal of the World Aquaculture Society 20, 223-229.

https://doi.org/10.1111/j.1749-7345.1989.tb01006.x

Watanabe, W. O., Ellingson, L. J., Olla, B. L., Ernst, D. H., \& Wicklund, R. I., 1990. Salinity tolerance and seawater survival vary ontogenetically in Florida red tilapia. Aquaculture 87, 311-321. https://doi.org/10.1016/0044-8486(90)90068-X

Young, B. C., Alfaggeh, R. H., \& AlMoutiri, I., 2021a. Growth, fry production, and cost analysis for Sabaki tilapia production systems. North American Journal of Aquaculture 83, 290-293. https://doi.org/10.1002/naaq.10189

Young, B. C., Alfaggeh, R. H., \& AlMoutiri, I., 2021b. Status and cost analysis of Sabaki tilapia farming in Saudi Arabia. Aquaculture International 29, 871-878. https://doi.org/10.1007/s10499-021-00663-z

Young, B. C., \& Alfaggeh, R. H., 2021. Entirely Farm-raised Snubnose Pompano (Trachinotus blochii) Under High Salinity in Saudi Arabia. Israeli Journal of Aquaculture Bamidgeh 73, 1546070. https://doi.org/10.46989/001c.31013

Young, B. C., \& AlMoutiri, I., 2022. Effects of high salinity on the larviculture of Asian sea bass Lates calcarifer in outdoor systems. North American Journal of Aquaculture 84, 112-115. https://doi.org/10.1002/naaq.10222

Zhang, Z., Zhang, Y., Li, F., Yang, H., Yuan, Y., \& Yuan, X., 2016. Economic efficiency of small-scale tilapia farms in Guangxi, China. Aquaculture, Economics and Management 21, 283-294. https://doi.org/10.1080/13657305.2016.1180644 